\author{
BARBARA MICHALAK-PIKULSKA \\ Uniwersytet Jagielloński w Krakowie \\ e-mail: barbara.michalak-pikulska@uj.edu.pl \\ SEBASTIAN GADOMSKI \\ Uniwersytet Jagielloński w Krakowie \\ e-mail: sebastian.gadomski@uj.edu.pl
}

\title{
Film in Nağīb Maḥfūẓ’s Literary Experience
}

\begin{abstract}
Nağīb Maḥfūẓ remains most often identified with literary prose creativity, which clearly dominated his artistic output. We rarely reminisce about his dramatic works, and we occasionally return to the films that came out of his scripts. However, as we read in the memoirs of the Egyptian Nobel Prize winner, film was his first great passion. Mahfüz, adoring the cinema, never wanted to become part of the world of the tenth muse and, incidentally, met in 1947 with the director Salāh Abū Sayf, who offered him a collaboration. The romance of the famous Cairo Trilogy's writer with the world of cinema lasted until 1959, bringing fruit in nearly thirty scenarios. Most of them brought popularity not so much to Mahfüz himself as to the directors and actors who were cast in the main roles. Films such as Al-Fitiwwa, $\breve{G} a$ 'alūnī muğriman, Al-Mudnibün or Rayā wa-Sakina are considered to be the most important achievements of the Egyptian cinematography.

This paper attempts to look critically at Nağỉb Maḥuuz's film output by placing scripts of the Egyptian Nobel Prize winner in the context of his literary prose.
\end{abstract}

Keywords: Nağīb Maḥfūz, Egyptian Nobel Prize winner, Egyptian cinema, Egyptian film.

In 1996, the organizers of the twentieth edition of the Cairo Film Festival, in celebration of the centenary of the world cinematography, asked a group of filmmakers and critics to select a hundred of the best Egyptian films, in their opinion. To a great surprise of everyone, among the screenwriters of the selected film productions, the second place went to Nağīb Maḥfūz, with the achievements of nine films, just after 'Alī az-Zarqānī. In addition, there were six films in the winning one hundred, for which the Egyptian Noble Prize winner co-created script adaptations, and ten films, which were based on his novels and short stories. Therefore, ultimately, among the hundred best Egyptian films there were twenty-five films, the creation of which was contributed by the author of the Cairo Trilogy, one way 
or another. ${ }^{1}$ No one was surprised that the film adaptations of Mahfūz works received the highest praise, the information that his scripts were rated as high was surprising. This was due to the fact that the cooperation of the Noble Prize winner with the Egyptian filmmakers was not too intense and it was still recognized as an episode in his artistic career.

Nağîb Maḥfūz, thanks to his rich prose works, is mainly associated with his novels. Also, in terms of his achievements on this level, he usually becomes the subject of studies and scientific investigations. We rarely remember Mahfüz as a playwright, and we mention his surname even less often in the context of reflections on the Egyptian film art. In the meantime, he himself, commonly known for his love of literature and philosophy, has never hidden his weakness for the cinema, and his interest in the tenth muse has already begun in early childhood. In the conversation with Rağā an-Naqqāš, mentioning his first encounter with the film, he said:

My relationship with the cinema started very early. I was only five years old when I entered the cinema called Al-Klūb al-misrī that was in the neighbourhood of Ḩān Ğa'far district in front of the al-Husayn mosque. [...] From the very first moment I fell in love with the cinema and regularly visited it in the company of my maid, whom my mother told to wait until the end of the show and then take me back home. The moment in which the words "the end" appeared was the most painful for me. I dreamed of spending all day in the movie theater. I dreamed of living in the cinema and never going out of it. ${ }^{2}$

As it is known, the child's fascination of Mahfūz did not result in the future plans of combining the writer's professional life with the cinema, nevertheless, as we can imagine, it had quite an impact on shaping his imagination and sensitivity of the aesthetic sense. The Egyptian Nobel Prize winner was primarily concerned with literature and nothing foretold that he will become seriously involved in working for the film. However, at the end of the 1940s, an accident has made Mahfüz start cooperation with the Egyptian filmmakers. In the conversation with Ğamāl al-Ḡîțānī mentioned that:

The cinema came into my life from the outside. I knew nothing about it. True, I used to like to watch movies, but how was the movie made? I had no idea. All I knew was that this movie was by Rudolph Valentino, that by Mary Pickford, and so on. I didn't know that there was a screenplay writer or anyone else. In 1947 my friend Fu'ad Nuwayra told me that Salah Abu Sayf, the director, wanted to meet me. ${ }^{3}$

Maḥūz had already a set of short stories and several novels in his achievements, including Al-Qāhira al-Ğadīda (New Cairo, 1945), Hān al-Halīlī (Khan al-Khalili, 1946) and Zuqāq al-Midaqq (Midaq Alley, 1947). During the conversation, the director was to say: "The fact is, I read your Khufu's Wisdom and it became clear to me from that that you could be a good screenplay writer." ${ }^{\text {A }}$ Although

${ }^{1}$ Cf. Walīd Sayf, Sinimima Nağ̄ib Mahfūz. Al-Fann al-ğamā ‘’̀ wa-al-ibdā' al-mutafarrid, Cairo 2015, p. 29.

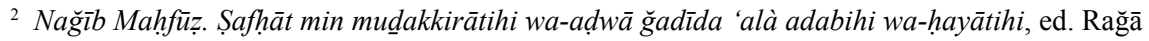
an-Naqqāš, Cairo 1998, p. 113.

${ }^{3}$ Nağ̄ib Maḥūz as cited in G. al-Ghitani, The Mahfouz Dialogs, Cairo 2007, p. 132.

${ }^{4}$ Șalāḥ Abū Sayf as cited in G. al-Ghitani, op. cit., p. 132. 
the writer did not have any experience in working on the film, Șalāh Abū Sayf proposed cooperation on the adaptation of the story of 'Antar and 'Abla. Encouraged both by his friend and the director himself, Mahfūz finally agreed to take the risk of facing a completely new artistic challenge, thus initiating an adventure with film lasting for many years, though generally not to intense. The writer also mentioned that at that time his publications did not yield any income. While in the film he was promised a decent financial gratification. ${ }^{5}$ While it is difficult to believe that this was the main argument for undertaking cooperation with Șalāh Abū Sayf, it could certainly be a kind of incentive to consent to it. After the years, the writer said: "For work on the film I received a hundred Egyptian pounds, which was a unique event in my life, something that resembled the discovery of oil in the Gulf countries." It is worth mentioning that the salary he received in 1944 working in the Ministry of Religious Affairs was only eight pounds. ${ }^{7}$

The director himself explained to Mahrüz what his task was to do and how he should prepare his texts. In addition, he provided him with books on film and cinema. The writer also made every effort to develop his workshop skills by studying the available literature on the art of scriptwriting. But he clearly stated that it was Șalāh Abū Sayf who taught him this job. ${ }^{8}$ In a short time, thanks to his literary skills and practice Mahfüz became a professional member of the film production crew. He even registered himself as a screenwriter in the syndicate so he could cooperate with any director.

Initially, the writer collaborated exclusively with Șalāh Abū Sayf, as he was the only one who produced only one film a year. Mahfüz suffered from allergy, which worsened during the summer, weakening his sight. At that time, he was not able to deal with his greatest passion of literature, but he could use this somewhat summer time for working on the film. The period of the writer's most intense involvement in editing scripts was in the 1953-1959 years, when after completing the Cairo Trilogy Mậuzu had a break for about five years in writing. In 1959, the writer took the position of the director of censorship in the ministry, and since then, for obvious reasons, he has completely ceased cooperation with filmmakers. However, on the basis of the previously signed contracts, a number of productions were performed, the creation of which involved Maḥūz. At his request, the evaluation of these films was performed by the then representative of the ministry of culture, 'Abd al-Mun 'im aș-Sāawī. ${ }^{9}$ It is worth pointing out that the writer, when accepting the position in the censorship department, consciously resigned from the high salaries, offered by the film industry for a modest state salary. The last film which showed the surname of Mậfūz was Al-Muğrim (The Criminal) from 1978.

Apart from the mentioned Șalāh Abū Sayf, the Noble Prize winner cooperated with many other directors, such as: 'Āṭif Sālim, Niyāzī Muștafà, Tawfīq Ṣāliḥ,

\footnotetext{
${ }^{5}$ Cf. Nağīb Mahfüz. Șaf̣āt min..., p. 114.

${ }^{6}$ Ibid.

${ }^{7}$ Cf. Ğamāl al-Ḡîțānī, op. cit., p. 99.

${ }^{8}$ Cf. ibid, p. 133.

${ }_{9}$ Cf. Nağ̄ib Mahfüz. Șafhāt min..., p. 115.
} 
Ḥasan Ramzī, Yūsuf Šāhīn, Faṭinn 'Abd al-Wahhab, Kamāl aš-Šayh, Ḥasan al-Imām, Husayn Kamāl, Sa ‘īd Marzūq, Ḥusām ad-Dīn Muștafà, Nūr ad-Damardāš and Ibrāhim as-Sayyid. His duty on the film was primarily about working with the entire team preparing the script. Maḥfüz's task was also to adapt literary works, write film narratives and dialogues.

The Egyptian Noble Prize winner mentions that he has co-created about thirty films. ${ }^{10}$ Walīd Sayf proves that the writer's name appears in thirty-one cinematographic productions. Due to the involvement of Mahfüz and his participation in their implementation, they can be divided into two groups. The first one is the projects, in which he participated as a screenwriter. While the second one is the undertakings, for which the writer prepared the texts of film narratives or their adaptations.

In the case of nineteen film productions, the Noble Prize winner appears as the author or co-author of the script. It is worth pointing out that $\mathrm{Al}$-Mugr rim from 1978 is a rework of the production entitled Laka yaum ya Zālim (Your Day Will Come) from 1951, and therefore, both films are sometimes treated as the same artistic project. ${ }^{11}$ Out of the nineteen films mentioned, Mahfūz wrote scripts on his own for three of them. These are At-Tarìq al-masdūd (Impasse, 1958), Anā hurra (I Am free, 1959) and Ehna at-talämida (We, the Students, 1963). As for the adaptations or stories written for specific production in mind, twelve feature films have been produced on their basis.

The vast majority of films, in the performance of which the Egyptian Noble Prize winter was involved, bears the marks of the critical realism and in a great deal harmonizes with his prose works. Above all, what we find in them is the compendium of the biggest problems, which affected the inhabitants of Egypt in the forties, fifties and sixties. They bring a multicoloured picture of the society, which is painfully experiencing the struggle taking part between its layers differentiated in terms of customs and economy. We often have to deal with the transfer of real events taken from the Egyptian daily lives into the cinema. This is the case with the films Rayā wa-Sakina (Raya and Sekina, 1953), Al-Wahašs (The Monster, 1954) or Sāhir an-nisā' '(Betrayer of Women, 1958). Particular attention should be paid to the first of these productions because it tells of the real events that shook Egypt in the early twenties of the last century. The film is related to the story of two women, who murdered in Alexandria, and then robbed mostly young girls. The Egyptian filmmakers returned to this thread many times, and in 2005 on its basis Ğamāl 'Abd al-Hamīd made a series also entitled Rayā wa-Sakina.

The action of most of the films co-created by Mahfūz takes place in poor districts, mostly in Cairo. The events rarely take place in the province, as it can be observed in the productions entitled Al-Fitiwwa (The Thug, 1957), Al-Wahaš or At-Tarīq al-masdūd. However, it should be noted that the action of some films, that were produced with Mahfüz collaboration, moves the viewers into spaces completely different from the Egyptian contemporary times. An-Nāsir Șalāh ad-Din (Saladin the Victorious, 1963) speaks about the epoch of the Crusades.

\footnotetext{
${ }^{10}$ Cf. ibid.

${ }^{11}$ Cf. Walīd Sayf, op. cit., p. 73.
} 
Ğamilla (Jamila, the Algerian, 1958) refers to the true story that took place during the bloody struggles of Algerians with French colonizers. The action of the film of Allähu akbar (God is the Greatest, 1959) takes place on the Arabian Peninsula at the time of the birth of Islam, and Muḡāmarāt 'Antar wa- 'Abla (The Adventures of Antar and Abla, 1948) invokes the well-known Arab epic and the world of Bedouin tradition.

In the films co-created by Mahfüz, the middle class is illustrated most often, although we can see quite a large variation in its wealth status, education, or worldview. For example, a young teacher Fā'iza from the film At-Tarīq al-masdūd and the wife of Ra'ufa, police officer from the picture Al-Wahaš live in different financial conditions. The contradictory worldviews, resulting from the intellectual aspirations, are professed by Šafā'ât from Šabāb imrā'a (A Woman's Youth, 1956) and Amīna from Anā hurra. Similar differences within the same social class can be found for example, in the productions entitled Ehna at-talämida, Muğrim fì iğāza (Thief on Holiday, 1958) or Sāhir an-nis $\bar{a}$.

The Egyptian Noble Prize winner in his scripts, adaptations and film narratives has also presented the world of the poorest inhabitants of Cairo several times, as is the case in the films Darb al-mahäbīl (The Fools' Alley, 1955) or Fitiwwāt al-Husayniyya (The Thugs of al-Husayniyya, 1954). On the other hand, he is not estranged with the circles of financial elites, both in the great agglomeration of Cairo and in the provinces, as demonstrated by the very popular productions entitled $\mathrm{Al}$ -Mudnibūn (The Guilty, 1976) or Al-Wahaš. Mahfūẓ also often presents, with great skills and cinematic success, quite a dark environment of murderers, criminals and thieves that come from different backgrounds and social layers. The most known films with the criminal theme, co-created by the writer, without a doubt include the Al-Wahăš, Rayā wa-Sakina, Ğa 'alūnī muğriman (They Made Me a Murderer, 1954), An-Namrūd (The Bad Tempered One, 1956), Al-Fitiwwa, Al-Mudnibūn, and finally Al-Mugrim. ${ }^{12}$ It is also worth noting that the plot of the productions co-created by the Egyptian Noble Prize winner has been embedded in a specific world of artists several times: painters, sculptors and writers, as exemplified by Šay' min al- 'ad̄āb (Something from the Sufferance, 1969) and Al-Ihtiyār (The Choice, 1970). The film called Al-Muntaqim (The Avenger) from 1947 deserved special attention. Its action takes place in the environment of chemists. Placing events in such an environment is a peculiar rarity in the history of Egyptian cinema. The creators of the film have used the specifics of a chemistry lab full of dangerous reagents and mysterious substances in an interesting way to show the dramatic love story, which despite tragic moments finally finds a happy ending.

From the very beginning of the cooperation of Maḥfūz with Șală Abū Sayf, the writer's great care can be noticed for the creation of credible and fully personalized foreground and background characters. The Noble Prize winner clearly departs from the static model of a hero, stereotypical in the Egyptian cinema in the forties, whose fate fits into the uncomplicated, predictable and schematic plot.

${ }^{12}$ It is worth pointing out that the film entitled $A l-M u \underline{d}$ nibūn on the popular YouTube portal now has over two million views. 
Maḥūz is trying to make his film characters live, dynamic heroes, who come from different backgrounds and have diverse experiences and aspirations, but who still bring in the potential of auto-creation and psychological transformation. They face daily hardships in different circumstances. Sometimes, the cause of their troubles is the miserable fate, as in the Imbirāturiyyat mim (Empire of M, 1972) film, other times, they complicate their own life, which is shown in a suggestive way by Ehna at-talämida. However, each time they retain the character and exceptional uniqueness of their own biographies and personalities. What is also important, we get to know the motivation of their actions from different points of view. This allows us to better understand their decisions, attitudes and situations, in which they are found. The Egyptian Noble Prize winner does not leave even the least significant figures without satiating them with individuality of a specific person. We can see it in seemingly trivial, briefly spoken words, looks, gestures, and even in the manner of clothing. All these elements, along with the scenography, create a rich, absorbing and attractive message, which, in addition to its basic entertaining dimension, is also saturated with ethical and social tones. However, it does so without intrusive didacticism or pretentious moralizing. We can see this clearly, for example, in the films Muğrim fi ĭğazza or Ehnna at-talämid̄a, where the characters entangled in disturbed family relationships and unable to implement their plans and aspirations are depraved, and enter the crime path, a little bit on their own request, and a little bit due to the unfavourable fate.

Many films, which involved the Mahfüz participation, undertake the issue of the women's situation in the Egyptian society. Although some motifs are constantly repeating themselves, they try to avoid stereotypes. The productions Darb al-mahäbill, Al-Hāriba (The Fugitive, 1958), Imbirātururiyyat Mìm, Šay'min al- 'ad̄āb, Sāhir annis $\bar{a}$ ' bring about the image of women who are the victims of a difficult economic situation, cultural conditions, as well as unhappy, or sometimes even toxic love. On the other hand, in films, such as Šabāb imrā'a or Anā hurra we find female characters, who take the initiatives themselves and in spite of tradition, culture and convention, consciously pursue their goals. They do not want to be passive role-players, who were written for them by others, but they direct their own loves bravely.

It should be noted that many film productions co-created by Maḥüz constitute adaptations of literary works. The narratives of Iḥsan 'Abd al-Quddūs dominate here. The movies like Bi'r al-hirmān (Well of the Deprivation, 1969), Imbirāturiyyat Mìm, Anā ḥurra and At-Tarīq al-masdūd, and others, were inspired by his novels and stories. In addition to the works of this author, also the literary works of Amīn Yūsūf and Yūsūf as-Sibā'ī were used. It is worth mentioning that the script for the Laka yaum ya zălim film was created based on the Emil Zola's story entitled Teresa Raquin.

In the conversation with Ğamāl al-Gīịtānī Nağî̉ Maḥfūz mentioned that it was extremely strange that in the times he wrote scripts and adaptations for subsequent film productions, nobody was interested in screening his own literary works. As he says: "I would find people telling me they were difficult." ${ }^{13}$ Only when, at the

${ }^{13}$ G. al-Ghitani, op. cit., p. 133. 
end of the fifties of the last century, Ahmmad 'Abbās Șālih recorded a radio play based on the Bidāya wa-nihāya novel (The Beginning and the End, 1949) under the same title for the station Șawt al-'Arab, the film producer, 'Abd al-Halīm Naṣr, was accidentally interested in it. He soon signed an appropriate contract with the writer, and the first film based on the novel of the Egyptian Nobel Prize winner was directed in 1960 by Șalāh Abū Sayf. ${ }^{14}$ Interestingly, Maḥfūz did not participate in the preparations for this production, or the others, which were based on his literary works. The next novels, which were screened soon, already in 1963, in the cinemas were Zuqāq al-Midaqq and Al-Liṣs wa-al-kilāb (The Thief and the Dogs, 1961). While the stories of the Egyptian Noble Prize winner debuted in their film versions in 1968, when the director Ibrāhīm aș-Ṣhan filmed fragments of the collection entitled Dunyā Allāh (God's World, 1962). Over the years, Egyptian filmmakers have increasingly found the inspiration in the writer's literary output, both his novels and stories. The current record of films produced based on the works of Mahfüz is over sixty productions.

In spite of taking part in more than thirty film projects and substantial material benefits that resulted from it to the writer's private budget, he never concealed the fact that working on a film was only a substitute for him, something that allowed him to survive a break in his literary work. ${ }^{15}$ He openly said that creating scripts did not give him pleasure, but was something contrary to his nature. In the conversation with Ğamāl al-Ḡîtān̄ì he mentioned:

The fact is I wasn't happy writing screenplays. As a writer, one is the master of one's work, but that kind of collective creation - you say 'right', you find someone else telling you 'left' is better, some of these points of view being well conceived technically, some commercially conceived, yet others because the person likes a particular actress - I wasn't happy with that way of working. ${ }^{16}$

While in the interview with Rağā an-Naqqāš he added:

I came to the conclusion that the external pressure I felt was too distressing and that I could not live with it any longer. Without regret, I withdrew from working with the world of film at the first opportunity. I lost the hope I had for a while when I was involved in a movie when I discovered the limitations of my work. So I started to treat it exclusively as an additional source of income. ${ }^{17}$

Although the Noble Prize winner's comments on his experiences from cooperating with filmmakers are very bitter, he seems to be too critical of his own achievements in the field of adaptation and screenwriting. It is true that he never published his own film stories, but as Walīd Sayf proves, their artistic values do not raise the slightest doubt. It is similar with the scripts, which despite of being created in a team and somehow under the dictation of producers and directors, have features of the unique style of the author of the Cairo Trilogy.

${ }^{14}$ Cf. Nağīb Maḥfūz. Șafhāt min..., p. 115.

${ }^{15}$ Cf. Nağ̄ib Maḩū̄z yatadakkar, ed. Ğamāl al-Ḡìțānī, Cairo 1980, p. 101.

16 G. al-Ghitani, op. cit., p. 133.

${ }_{17}$ Nağ̄ib Maḥūz. Safḥāt min..., pp. 121-122. 
It must be admitted that not all films, where the surname of Mahfūz appeared during the making, are the outstanding achievements of the Egyptian cinematography. However, in the context of the studies of the writer's work, all of them remain an extremely valuable source illustrating the vast scope of his artistic achievements and interests. In this way they set new directions for research on the achievements of the Noble Prize winner and inscribe his outstanding artistic personality into unconventional contexts.

\section{Bibliography}

Gamal al-Ghitani, The Mahfouz Dialogs, Cairo 2007.

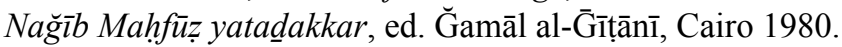

Nağ̄̄b Maḥfūz. Șafḥāt min mudakkkirātihi wa-aḍā ğadīda 'alà adabihi wa-hayātihi, ed. Rağā an-Naqqāš, Cairo 1998.

Walīd Sayf, Sìnimā Nağ̄̉b Mahfūz. Al-Fann al-ğamā's wa-al-ibdā' al-mutafarrid, Cairo 2015. 